\title{
Discourse Analysis in E-Learning-Based Course Using Moodle Platform: An Experimental Design
}

\author{
Silvia Eka Putri ${ }^{1}$, Budianto Hamuddin ${ }^{2}$, Mutia Sari Nursafira ${ }^{3}$, and Tatum Derin ${ }^{4}$ \\ 1,3,4 Universitas Lancang Kuning, Pekanbaru, Indonesia \\ ${ }^{2}$ Universitas Hasanuddin, Makassar, Indonesia \\ budihamuddin@pascaunhas.ac.id
}

\section{ARTICLE HISTORY}

\author{
Received : 2020-04-21 \\ Revised : 2020-04-24 \\ Accepted : 2020-04-25
}

\section{KEYWORDS}

Information and Communication Technology (ICT)

English as a Foreign Language (EFL)

E-learning

Discourse Analysis

Moodle

\begin{abstract}
The COVID-19 pandemic has caused educational institutions all over the world to migrate their teachings online. Since Indonesian government issued the SK Mendiknas No. 107/U/2001, educational institutions had to steadily integrate their learning process with technology. So, this study intends to investigate the effectiveness of using the open-source learning platforms known as Moodle in a selected university, Universitas Lancang Kuning (Unilak) in Indonesia. While multiple courses uses Moodle, this study selected to analyse the 2017/2018 fifth semester students as they are the ones who pioneered Moodle for other classes to use. With a quasi-experimental research design, this study used four types of test to calculate the results of the essay pre-test and post-test on both experimental and control classes. With the eventual mean of 65.53 for the experimental class and 63.25 for the control, this study proved that Moodle does effectively improve Indonesian university EFL students' learning compared to conventional lecture-style learning. Future research is hoped to extend or compare this study with an investigation on how university EFL students are using e-learning during the COVID-19 pandemic and other factors that have not been covered in this empirical study.
\end{abstract}

\section{Introduction}

In line with developments in information and communication technology (ICT), the trend of elearning as an alternative learning arose. Al-Fraihat, Joy, Masa'deh, \& Sinclair (2019) state that e-learning has mainstreamed and has been massively adopted in higher education. Teachers and lecturers largely must adapt in using technology in their teaching as their students are part of the technological generation (Junaidi, Hamuddin, Simangunsong, Rahman, \& Derin, 2020). According to Choudhury \& Pattnaik (2020), "in the last two decades there have been various social, technological and organizational factors that have impacted the e learning stakeholders and no stakeholder influences the world of electronic learning in isolation."

Utilisation of information technology (IT) for learning activities in Indonesia nowadays is more conducive with the issuance of the Ministerial of National Education Decree (SK Mendiknas) number 107/U/2001. The decree encourages conventional schools to implement distance education, making the learning environment take on a dual-mode. Applying e-learning in teaching English as a Foreign Language (EFL) for students in the early stage is challenging for parties involved in education, especially considering the status quo of COVID-19 pandemic. This issue is an exciting topic to explore considering improvement on the effectiveness of e-learning programs also fulfils public expectation for the relevant higher education's quality.

This study placed its context on the Faculty of Teacher Training and Education (FKIP) in Universitas Lancang Kuning (Unilak). In early 2017, the Dean of FKIP Unilak in Pekanbaru city initiated the blended-learning project using Moodle to enhance the learning environment and to raise the FKIP students' IT skills both in teaching and learning. This program provides convenience to lecturers as well as students who have mileage and time, to keep doing learning activities through e-learning media.

Many types of online tools are tried out for various classes in FKIP Unilak. Lecturers and student who are training to be teachers integrate their lessons on Google Classroom and Kahoot to familiarise Unilak students with online learning (Putri, 2019). YouTube videos and social networking sites such as LINE and WhatsApp are used to supplement lecturers' lesson plans (Marwa \& Herdi, 2017; Risani, 2020; Yudar, Aditomo, \& Silalahi, 2020). The university's blended learning online platform steadily guides students to understand and refer to global and advanced academic sources such as Elsevier, Springer Nature, Wiley-Blackwell, Taylor \& Francis, and Sage (Harianja, Yudar, Deliani, Nursafira, \& Hamuddin, 2019). Hamuddin, Syahdan, Rahman, Rianita, \& 
Derin (2019) show that blogging is a consistent alternative learning media that FKIP Unilak students use to practice and create their online writing track record since 2016. Future studies may identify and investigate the use of other online tools in this selected university, but this study focused on the open-source learning platform, Moodle.

'Moodle' stands for Modular Object-Oriented Dynamic Learning Environment. This platform is one of the "world's most popular Learning Management Systems (LMS) for both learning and training in various disciplines (Klaus, 2005), most probably because it is user-friendly, open-source, and free to download" (Bataineh \& Mayyas, 2017; Solutions, 2017). Unilak lecturers use Moodle to manage their students learning in distance because it serves as a useful tool by providing learning facilities with important supporting features. Moodle features rally on management on tasks, quizzes, chats, and uploads of various learning material formats (Liu, Atif, Froissard, \& Richards, 2019). Moodle makes distant learning more comfortable to understand because the information is served not only with text but also with additional pictures and videos.

\subsection{Blended Learning in FKIP Unilak}

Universitas Lancang Kuning (Unilak) has undergone the primary transformation of adopting blended learning style for their curriculum. The move is partly motivated due to lack of budget, significant increase in the number of university students, the generational change of student population, and the upto-date nature of online sources that cannot possibly be ignored. Through e-learning, the feasibility of learning with no time limitation proportionate to the students' requirements has been brought about. In comparison to the traditional learning which might disregard the students' requirements and unable to address a student at a specific time and place, elearning is an excellent strategy to deal with the problem (Farajollahi \& Zarifsanaee, 2012).

To facilitate and support the distance learning of FKIP Unilak, Moodle is one of the many e-learning platforms that are used as a learning management system (LMS). Instructions to use Moodle were first disseminated in the university's blended-learning platform that can be accessed in https://blendedlearning.unilak.ac.id/ which can be freely accessed by all students of Unilak. Moodle is used by lecturers in three study programs in FKIP, namely Biology Education, Early Childhood Education, and English Education Departments. In the case of the latter, Discourse Analysis, Reading III, Basic English Grammar, and Interpreting are some courses in the English Education Department of FKIP Unilak that already use Moodle. Among these courses, Discourse Analysis (DA) is an excellent choice for this study to focus on as it is the course starts using Moodle earlier than other classes. Researchers also chose DA course over others because according to Herlinawati, Saukah, Mukminatien, Isnawati, \& Bastian (2020), "composing linguistically accurate paragraphs was the most 'challenging' factor of complex writing process encountered by (Indonesian) university students majoring in English," (p. 69). Compared to the other courses that also uses Moodle, DA course is a more high-stakes class because it is an advanced material and the results of this empirical study will greatly benefit further refinement of FKIP Unilak's elearning.

\subsection{Teaching English Using Moodle}

The key advantage of using Moodle is the lack of requirement for an official or paid license to use the platform. Educators need only to modify its system to fit their faculties' procedures and policies. Additional advantages of Moodle include its wide array of economic, technological, academic, and philosophic benefits. Furthermore, teachers' and students' perceptions have been proven to be largely positive in using Moodle for teaching and learning. Moodle's usefulness and ease of use have been identified as the main two factors that influence the usage of Moodle for learning, according to a survey on 564 students from nine departments at the University of Macau (Teo, Zhou, Fan, \& Huang, 2019).

Cigdemoglu, Arslan, \& Akay (2011), for example, conducted for the first time in a private university in Turkey, a qualitative study of instructors' attitudes and experiences with Moodle in their classes. The researchers had coded the interviewing answers into eight themes: (a) Need to Use; (b) Learning and Interest; (c) Expectations; (d) Grade-Book and News Forum; (e) Students' Level of Participation; (f) Students' Impression; (g) Advantages; and (h) Disadvantages. This in-depth investigation revealed that "the more an instructor has used the tool, the more beneficial they find using the tool," (Cigdemoglu, Arslan, \& Akay, 2011, p.795).

However, there are some aspects that were found wanting in Moodle-based learning. Average waiting time for a response, feedback quality, material thoroughness, material clarity, website userfriendliness, cooperation diversity, and material quantity were found to be characteristics that needed to be addressed further for maximal satisfaction for students, particularly females according to a study that focused on the perceptions between male and female students in the University of Belgrade (Horvat, Dobrota, Krsmanovic, \& Cudanov, 2015).

More recently, in Taiwan, Chang \& Lan (2019) explored undergraduate EFL students' perceptions of using Moodle for their Reading course. While perceptions were dominantly positive in claiming Moodle to be helpful, the researchers found that the density of the students' post-test summaries were relatively the same with the summaries of their pretest. 
So far, the application of Moodle in classrooms has been investigated in Turkey, China, Serbia, and Taiwan. There are certainly more similar studies that are not covered in this literature review, but it seems that an experimental study on Moodle's application in an Indonesian EFL classroom hasn't been conducted. The studies found within the context of Moodle and Indonesia are Kautsar, Musashi, Kubota, \& Sugitani (2014) that focused on developing the plugin call function, Paturusi, Chisaki, \& Usagawa (2014) that used Moodle to investigate the application of online quizzes for mathematics students, Sulisworo, Agustin, \& Sudarmiyanti (2016) that applied Moodle on a secondary school's Physics course, and Sari \& Setiawan (2018) that used Moodle for economic learning. Therefore, this study aims to address the gap of investigating Indonesian university students' application of Moodle for the improvement of their EFL. The results of this experimental study is hoped to aid the design and development of high-quality LMS-based courses in university-level.

\subsection{Teaching Discourse Analysis Course with Moodle}

The definition of 'discourse' reflects a focus on the linguistic point of view, especially that of applied linguistics. Discourse refers to the speech patterns and the analysis pinpoints how language, dialects, and statements are used in a particular community. Discourse as a subject of study looks at the discourse among people who share the same speech conventions Moreover, discourse refers to the linguistics of language use of understanding interactions in a social context, specifically the analysis of occurring connected speech or written discourse (Derin, Putri, Nursafira, \& Hamuddin, 2020).

Discourse analysis (DA) focuses on the relationship between language forms and a limited sense of context. It tends to be oriented to a narrow understanding of the broader social, cultural and ideological forces that influence our lives (Ainsworth, 2017). Then, critical discourse analysis (CDA) goes much further toward addressed the ideological dimensions of discourse (Van Leeuwen, 2008).

Since Moodle framework is capable to be adapted in many activities in teaching and learning process, this experimental research has applied activities such as database entry, knowledge transfer, schedule planning, texting, online quiz and assignment in the DA course. This present study tries to set Moodle platform in teaching CDA topic in DA course at the fifth semester of FKIP Unilak, Pekanbaru, in order to see whether Moodle can be effectively used to support the e-learning in the university level.

\section{Method}

The research aims to find out the effectiveness of Moodle platform in the e-learning process for DA course. The research based its framework on experimental to establish possible cause and effect consists of two variables (Zulkarnain, 2012). The independent variable $(\mathrm{X})$ refers to the use of Moodle platform in e-learning-based course, and the dependent variable (Y) refers to students' ability in DA class.

The quasi-experimental design is chosen as it is suitable to be implemented in this condition. The reasoning lies on how this design allows the researchers to design the pre- and post-tests in between-group research including non-random assignment to participants or groups (Creswell, 2002). This research was conducted on the fifth semester students (Class A \& C) of English Education Department in FKIP Unilak on 2017/2018 academic year. The duration of the study took place from December 2017 to the end of January 2018. The flow of this quasi-experimental study can be seen in figure 2.1 .

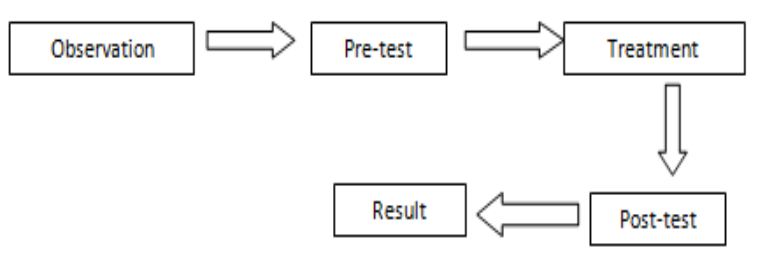

Figure 2.1 Experimental Research Setting

\subsection{Population}

The population of this research is the fifthsemester students of the English Education Department in FKIP Unilak. The sample chosen to represent the entire year are two classes, A and C, totalling to 53 students who are enrolled in Discourse Analysis course.

\subsection{Sample}

In this research, the researchers determined two classes as the sample by the recommendation of the lecturer involved. One class is designated as experimental class which is taught using Moodle, and the other as the control class which uses the traditional learning process.

Table 2.1 Sample of the Research

\begin{tabular}{cccc}
\hline No & Class & Number of Students & Class \\
\hline 1 & VC & 26 & Experiment \\
2 & VA & 27 & Control
\end{tabular}




\subsection{The Technique of Collecting Data}

The research used a test to measure the effectiveness of using Moodle platform in DA elearning. The test was conducted in the form of essay test. The 20-item essay test was given to the students in the pre-test and post-test phases to both of the classes during the appropriate time per the DA syllabus.

\subsection{The Technique of Analysing the Data}

To find out the significant difference between the experimental and control class by using e-learning with Moodle, the researchers statistically analysed the resulting data with the t-test if the data is regular and homogenous. If the data is not normal or not homogenous, the researchers analysed the results with the U Mann-Whitney test. The results are used to obtain an empirical view of the improvement of both classes' overall comprehension from the pre-test and post-test score. Then, the researchers calculated the averages of the pre-test and post-test scores with $\mathrm{N}$ Gain. N-gain is the primarily used method to obtain the effect size of the treatment that is given to the experimental class (Sugiyono, 2006).

\section{Findings}

The pre-test is completed by all students from both classes before the researchers give the treatment of using Moodle to the experimental class. The purpose of the pre-test is to determine the students' original ability before the treatment begins. The test is an essay test, and the results of the pre-test can be seen in table 3.1 .

Table 3.1 Descriptive Statistics of Pre-test Scores

\begin{tabular}{llllll}
\hline Class & $\mathrm{N}$ & Mean & Std. Deviation & Minimum & Maximum \\
\hline Experiment & 26 & 51,5385 & 13,91181 & 15,00 & 75,00 \\
Control & 27 & 52,9630 & 9,22572 & 35,00 & 65,00 \\
\hline
\end{tabular}

According to table 3.1, the minimum score of the experimental class' pre-test is 15.00 lower than the control class, who scored 35.00. The maximum score on the experimental class in the table is 75.00 , which is higher than the control class' maximum score of 65.00. Test of the students' concept mastery on the average is 51.53 for the experimental class. This score is lower than the control class' mean of 52.97. Figure 3.1 better illustrates the pre-test results of both classes.

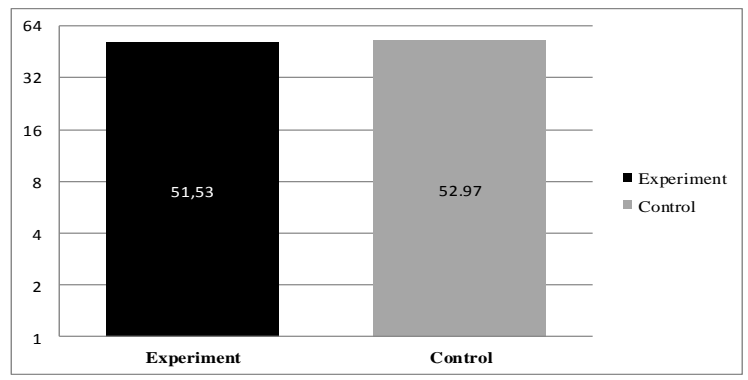

Figure 3.1 Comparison Pre-test Scores
Figure 3.1 clearly shows that the average of the experimental class is lower than the control class. The mean diagram of the experimental class averages on 51.53 and control class averages on 52.97. After obtaining the data on the average of pre-test results of both experimental and control classes, the researchers further calculated the results with the normality test, homogeneity test and continuity test of pre-test data by using parametric statistic, namely t-test.

The t-test can be used if the data distribution is normal and homogenous, while if data is not normal or not homogenous the U Mann-Whitney test will be used. The data is calculated by using nonparametric, namely U-Mann Whitney. Normality test is done to ascertain if the data distribution is normal or not. It is a requirement for establishing the next step in parametric or nonparametric statistics. The researchers used the Kolmogorov-Smirnov (KS-21) as the formula to procure the results of the normality test. The results of the normality test on the data results of the pre-test of both classes can be seen in table 3.2.

Table 3.2 Normality Test of Pre-test

\begin{tabular}{lllll}
\hline Class & $\begin{array}{l}\alpha \\
\text { (siguificantlerel) }\end{array}$ & $\begin{array}{l}\text { Asymp. Sig. } \\
\text { (2-tailed) }\end{array}$ & Hypothesis & Distribution \\
\hline Experimental & 0.05 & 0.186 & Ho accepted & Nomal \\
Control & 0.05 & 0.562 & Ho accepted & Nomal \\
\hline
\end{tabular}

Table 3.2 shows that normality test proved the pre-test data distribution is, indeed, normal. Experimental class in Asymp. Sig. (2-tailed) is 0.186 with significant level is 0.05 . If the data value of Asymp. Sig. (2-tailed) $0.186>0.05$, it means that the distribution of data is normal and controls the class value of Asymp. Sig. (2-tailed) $0.562>0.05$, meaning that the data distribution is also normal.

Afterwards, the researchers conducted the homogeneity test on the pre-test results. It is done to determine the quality of similarity of the sample. It is obtained by comparing the value of based on the trimmed mean, which is calculated with the Levene Formula. The experimental and control class' homogeneity test results is shown on table 3.3.

Table 3.3 Homogeneity Test of Pre-test

\begin{tabular}{lllll}
\hline Data & $\begin{array}{l}a \\
\text { (siguificantlerel) }\end{array}$ & $\begin{array}{l}\text { Asymp. Sig. } \\
\text { (2-tailed) }\end{array}$ & Hypothesis & Distribution \\
\hline Pre-Test & 0.05 & 0.108 & Ho accepted & Homogenous \\
\hline
\end{tabular}

Concerning table 3.3, the homogeneity test of pretest gain value based on Asymp. Sig. (2-tailed) is 0.108 with significant level 0.05 . It means the pre-test on experimental class came from homogenous variance. Considering Asymp. Sig. (2-tailed) 0.108 is larger than 0.05 , the pre-test data of both classes are, in fact, from the homogenous variance. 
Finally, because the data distribution of pre-test is normal and homogenous, the next test is the t-test. The Asymp. Sig. (2-tailed) on the pre-test is compared with significant level 0.05 , which is the same with the standard value of 0.05 . The similar numbers indicate that the data is not different significantly. The result of t-test on pre-test can be seen in table 3.4 .

Table 3.4 T-test Result of Pre-test

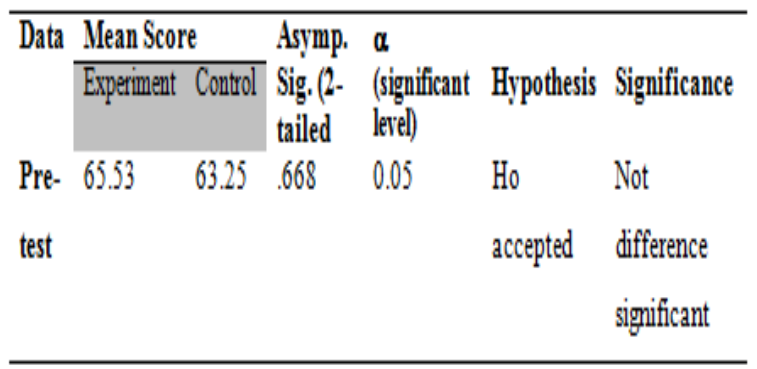

In table 3.4, t-test results of both experimental and control classes were not significantly different. This conclusion occurs because the value of Asymp. Sig. (2-tailed) is 0.139. It meant Asymp.Sig. (2-tailed) 139 $>$ significant level 0.05. Thus, between experimental class and control class, the results are not difference significantly different from each other.

With both classes' original and standard abilities established as relatively the same, researchers moved on to the post-testing. The data was collected in an identical manner with the pre-test, which is by an essay test for the DA course on the topic of CDA. Based on the data that had been collected, experimental and control classes yielded the results displayed on table 3.5.

Table 3.5 Descriptive Statistics of Post-test Score

\begin{tabular}{llllll}
\hline & $N$ & Mean & Std. Deviation & Minimum & Maximum \\
\hline Experiment & 26 & 65,5385 & 6,27523 & 50,00 & 85,00 \\
Control & 27 & 63,2593 & 7,03065 & 45,00 & 80,00 \\
\hline
\end{tabular}

Concerning table 3.5 above, the minimum score of the experimental class is 50.00 , which is higher than the control class' score of 45.00. For the maximum score and average score, the experimental class is higher than the control class. Where experimental class gets the maximum score 85.00 with the average score is 65.53 , the control class obtained a maximum score of 80.00 and an average score of 63.25 . The conclusion is that the post-test score of the experimental class is higher than the control class. The comparison of the post-test scores of both classes are better visualised on figure 3.2.

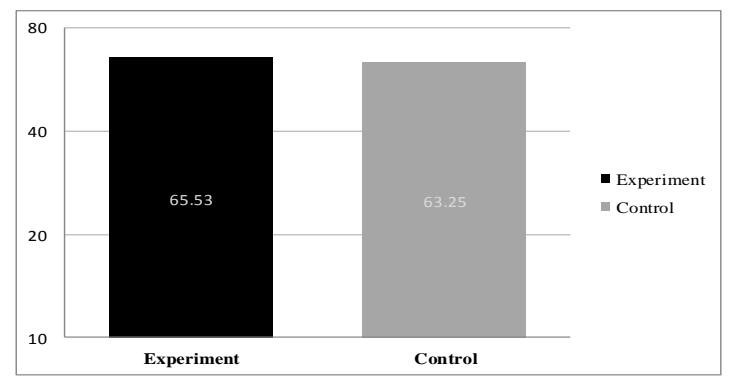

Figure 3.2 Comparison Post-test Scores of Experimental and Control Classes

Based on figure 3.2, this study found that the average post-test score of the experimental class is higher than the control class, the opposite case with the pre-test score.. The mean diagram of the experimental class achieves an average of 65.53, while the control class achieves an average of 63.25.

Similarly with the pre-test, the post-test data results are the tested multiple times with the normality test and the homogeneity test as the qualification for the continuing test. The result of the normality test on the post-test data can be seen on table 3.6.

Table 3.6 Normality Test of Post-test

\begin{tabular}{lllll}
\hline Class & $\begin{array}{l}\text { A } \\
\text { (significant } \\
\text { level) }\end{array}$ & $\begin{array}{l}\text { Asymp.Sig. } \\
\text { (2-tailed) }\end{array}$ & Hypothesis & Distribution \\
\hline Experimental & 0.05 & 0.113 & Ho accepted & Nomal \\
\hline Control & 0.05 & 0.123 & Ho accepted & Nomal \\
\hline
\end{tabular}

Table 3.6 shows that the experimental class' Asymp. Sig. (2-tailed) is 0.113 with significant level 0.05. As the data of Asymp. Sig. (2-tailed) $0.113>$ 0.05 , it means that the distribution of data is normal. The control class' Asymp. Sig. (2-tailed) $0.123>0.05$, which also means that the data distribution is also normal. This means that both classes' post-test data has a normal distribution. Next, researchers conducted the homogeneity test on the post-test scores, and the results is shown on table 3.7 .

Table 3.7 Homogeneity Test of Post-test

\begin{tabular}{ccccc}
\hline Data & $\begin{array}{c}\text { a } \\
\text { (significant } \\
\text { level) }\end{array}$ & $\begin{array}{c}\text { Asymp.Sig. } \\
\text { (2-tailed) }\end{array}$ & Hypothesis & Distribution \\
\hline Post-Test & 0.05 & 0.172 & Ho accepted Homogenous \\
\hline
\end{tabular}

As can be seen on table 3.7, the value of Asymp. Sig. (2-tailed) is 0.172 with significant level 0.05 , meaning that the post-test on experimental class is coming from homogeneous variance when based on Asymp. Sig. (2-tailed) $0.172>0.05$, it means that the post-test data both the classes form the homogenous variance. Since data are normal and homogenous, so the data can be calculated by using parametric t-test. The result of t-test on the post-test data can be seen in table 4.8 . 
Table 4.8 T-Test Result of Post-test

\begin{tabular}{|c|c|c|c|c|c|c|}
\hline \multirow[t]{2}{*}{ Data } & \multicolumn{2}{|c|}{ Mean Score } & \multirow{2}{*}{$\begin{array}{l}\text { Asymp } \\
\text {. Sig. } \\
\text { (2- } \\
\text { tailed }\end{array}$} & \multirow{2}{*}{$\begin{array}{l}\alpha \\
\text { (significan } \\
\text { tlevel) }\end{array}$} & \multirow{2}{*}{ Hypothesi } & \multirow[b]{2}{*}{$\begin{array}{l}\text { Significanc } \\
\mathrm{e}\end{array}$} \\
\hline & $\begin{array}{l}\text { Expenimen } \\
t\end{array}$ & $\begin{array}{l}\text { Contro } \\
1\end{array}$ & & & & \\
\hline $\begin{array}{l}\text { Post } \\
\text {-test }\end{array}$ & 51.53 & 52.96 & .249 & 0.05 & $\begin{array}{l}\text { Ho } \\
\text { accepted }\end{array}$ & $\begin{array}{l}\text { Not } \\
\text { difference } \\
\text { significant }\end{array}$ \\
\hline
\end{tabular}

Table 4.8 shows that the t-test result of both was not significantly different. This is because the value of Asymp. Sig. (2-tailed) is 0.249. It meant Asymp.Sig. (2-tailed) $249>$ significant level 0.05. As experimental class and control class are found equal, researchers moved to calculate the data with $\mathrm{N}$-Gain to obtain the effect size of the Moodle treatment on the experimental class. The result of the N-Gain can be seen on table 4.9 .

Table 4.9 N-Gain Score of Experimental Class

\begin{tabular}{cccccc}
\hline Test & N & \multicolumn{3}{c}{ N-Gain } & Average \\
\cline { 3 - 5 } & & Score Ideal & Min. Score & Max. Score & N-Gain \\
Pre-Test & 26 & 100 & 15,00 & 75.00 & 0.29 \\
Post-Test & 26 & 100 & 50.00 & 85.00 & \\
\hline
\end{tabular}

Table 4.9 shows that the average of $\mathrm{N}-$ Gain is 0.29 , meaning that the significance of the treatment, that is using Moodle-based learning, in the experimental class is in the middle level. This is because according to the criteria of achievement, N-Gain score can be said as a middle level if the score is $0.3<\mathrm{g}<0.7$. Therefore, the open-source learning management system Moodle gives a positive effect for the elearning of the fifth semester students of English Education Department in FKIP Unilak, Pekanbaru.

\section{Discussion}

The researchers analysed the results of the multiple statistical tests on the data of essay pre-test and post-test scores from students' discourse analysis comprehension. Based on the results of pre-test calculations, the experimental class (51.53) and the control class (52.96) were not significantly different. After giving the experimental class the treatment of using Moodle as the framework for their DA course, results of post-test calculations also showed that the experimental class (65.53) is not significantly different with the control class (63.25).

The key difference, however, is that during the pre-test, experimental class scored lower than the control class, but they scored higher in the post-test. The calculations with the normality test, homogeneity test, t-test, and N-Gain in overall led researchers to confirm that using Moodle as e-learning platform is effective for university EFL students.

\subsection{Teaching Discourse Analysis using Moodle}

From the results of this quasi-experimental study, the researchers conclude that Moodle in e-learning is indeed effectively used in teaching and learning by the Discourse Analysis course which pioneered its usage to other classes. The students' comprehension of the advanced material of critical discourse analysis is better than students who were taught with only the traditional, in-class lecture techniques.

This finding can be ascertained from the students' mean scores in the pre-test (51.53) and post-test (65.53). The post-test score is better than the pre-test, and this is true for both experimental and control classes. Although, as the experimental class who initially scored lower than the control class eventually scored higher, the researchers conclude that the treatment e-learning does give positive effects.

\subsection{Students' Results in Using Moodle}

The Indonesian university EFL students' who are taught without the Moodle platform in e-learning sometimes feel lack of interest and boring into the classroom. It is caused the students sometimes do not interested in the conventional method in the classroom and do not use another media or platform in a learning activity. Based on the fact, the score of the students who are taught using Moodle platform in e-learning can be seen from the result of the mean score in the control class in the pre-test (52.96) and post-test (63.25). They also have a different score, but it is still lower than the mean score in the experimental class.

\section{Conclusion}

This study used a quasi-experimental research design to statistically determine the effectiveness of the open-source learning platform known as Moodle for university EFL students. Fifth-semester students in FKIP Unilak who were enrolled in discourse analysis course during the 2017/2018 academic year became the focus as they are the ones who first started using Moodle for their e-learning process. One class is chosen as the control class in which the students are taught with only the conventional method, and the other class is chosen as the experimental class in which the students are taught with Moodle as the platform of their e-learning process. Both essay pretest and post-test results were finely calculated with normality test, homogeneity test, t-test, and N-Gain. In the end, the study found that the experimental class' average post-test score is 65.53 , higher than the control class' score of 63.25. The findings of this research show that students who are taught with the blended-learning style gains significant improvement than with traditional lecture-style learning. 
This study addressed the seeming research gap of empirical investigation on EFL university students' application of Moodle in Indonesia. In the future, researchers might be interested to compare the empirical findings of the application of Moodle or other online tools across different disciplines or different countries. Gender differences is suggested to be taken into account in future studies, as researchers of this quasi-experimental study should note that the students involved in this research are dominantly female. While student and teacher perceptions is a common and perhaps an unending avenue of research focus, researchers would like to recommend future studies to break down or develop the minutiae practical application of online tools, narrate the details of the transformation of conventional to online teaching, and study the completely exclusive elearning style that is occurring during the world-wide 2020 social distancing due to COVID-19 pandemic.

\section{Acknowledgement}

This research was supported by the Faculty of Teacher Training and Education (FKIP) in Universitas Lancang Kuning (Unilak). The researchers also thank their colleagues from United Kingdom Gang Out (UKGO) and Unilak-Research Advancement for Intellectual and Scientific Improvement (U-RAISE) Academy who provided aid in improving the language quality of this research article. However, the results and conclusions reached in this paper are of the authors', and might not be agreed by their colleagues.

\section{References}

Ainsworth, S. (2017).

Discourse Analysis/Methods. The International Encyclopedia of Organizational Communication, $1-14$.

Al-Fraihat, D., Joy, M., \& Sinclair, J. (2020). Evaluating E-learning systems success: An empirical study. Computers in Human Behavior, 102, 67-86.

Bataineh, R. F., \& Mayyas, M. B. (2017). The Utility of Blended Learning in EFL Reading and Grammar: A Case for Moodle. Teaching English with Technology, 17(3), 35-49.

Chang, M. M., \& Lan, S. W. (2019). Exploring undergraduate EFL students' perceptions and experiences of a Moodle-based reciprocal teaching application. Open Learning: The Journal of Open, Distance and e-Learning, 1-16.

Choudhury, S., \& Pattnaik, S. (2020). Emerging themes in e-learning: A review from the stakeholders' perspective. Computers \& Education, 144, 103657.

Cigdemoglu, C., Arslan, H. O., \& Akay, H. (2011). A Phenomenological Study of Instructors'
Experiences on an Open Source Learning Management System. Procedia-Social and Behavioral Sciences, 28, 790-795.

Creswell, J. W. (2002). Educational research: Planning, conducting, and evaluating quantitative (pp. 146-166). Upper Saddle River, NJ: Prentice Hall.

Derin, T., Putri, N. S., Nursafira, M. S., \& Hamuddin, B. (2020). Discourse Analysis (DA) in the Context of English as a Foreign Language (EFL): A Chronological Review. ELSYA: Journal of English Language Studies, 2(1), 1-8.

Farajollahi, M., \& Zarifsanaee, N. (2012). Distance Teaching and Learning in Higher Education: A Conceptual Model. International Perspectives of Distance Learning in Higher Education, 13-32.

Hamuddin, B., Syahdan, S., Rahman, F., Rianita, D., \& Derin, T. (2019). Do They Truly Intend to Harm Their Friends?: The Motives Beyond Cyberbullying among University Students. International Journal of Cyber Behavior, Psychology and Learning (IJCBPL), 9(4), 32-44.

Harianja, R., Yudar, R. S., Deliani, S., Nursafira, M. S., \& Hamuddin, B. (2019). An Analysis of Pronouns Used in Selected International Journal Articles: Exploring Authors' Flexibility and Consistency. REiLA: Journal of Research and Innovation in Language, 1(3), 73-78.

Herlinawati, H., Saukah, A., Mukminatien, N., Isnawati, U. M., \& Bastian, A. (2020). Do Comprehensive and Selective Corrective Feedback Really Work for L2 Writing Accuracy? An Overview from Indonesian Context. Humanities \& Social Sciences Reviews, 8(1), 69-77.

Horvat, A., Dobrota, M., Krsmanovic, M., \& Cudanov, M. (2015). Student perception of Moodle learning management system: a satisfaction and significance analysis. Interactive Learning Environments, 23(4), 515-527.

Junaidi, J., Hamuddin, B., Simangunsong, W., Rahman, F., \& Derin, T. (2020). ICT Usage in Teaching English in Pekanbaru: Exploring Junior High School Teachers' Problems. International Journal of Advanced Science and Technology, 29(3), 5052-5063.

Kautsar, I. A., Musashi, Y., Kubota, S. I., \& Sugitani, K. (2014, April). Developing Moodle plugin for creating learning content with another REST function call. In 2014 IEEE Global Engineering Education Conference (EDUCON) (pp. 784787). IEEE.

Klaus, B. (2005). Are You Ready to "Moodle"? Language, Learning and Technology, 9(2):16-23. 
Liu, D. Y. T., Atif, A., Froissard, J. C., \& Richards, D (2019, January). An enhanced learning analytics plugin for Moodle: student engagement and personalised intervention. In ASCILITE 2015Australasian Society for Computers in Learning and Tertiary Education, Conference Proceedings.

Marwa, M., \& Herdi, H. (2017). Do Native Speakers in Youtube Videos Benefit EFL Students' Phonological Appropriation?. Lectura: Jurnal Pendidikan, 8(2).

Paturusi, S., Chisaki, Y., \& Usagawa, T. (2014, September). Development and evaluation of online quizzes to enhance learning performance: A survey of student assessment through MOODLE in Indonesian National University. In Proceedings of International Conference on Information, Communication Technology and System (ICTS) 2014 (pp. 211-216). IEEE.

Putri, N. S. (2019). Kahoot Application in English Language Teaching (ELT) Context: An Alternative Learning Strategy. ELSYA: Journal of English Language Studies, 1(1), 11-15.

Risani, T. D. (2020). Writing News Item in English Language Teaching Context: Line Apps Platform for Senior High School Students. Utamax: Journal of Ultimate Research and Trends in Education, 2(1), 24-28.

Sari, A., \& Setiawan, A. (2018). The Development of Internet-Based Economic Learning Media using Moodle Approach. International Journal of Active Learning, 3(2), 100-109.

Solutions, L. (2017). The complete Moodle user guide. Retrieved 22 April 2020 from https://www.lambdasolutions.net/guides-andresearch/moodle-user-guide-intro-to-moodle

Sugiyono, DR (2006). Statistics for Research. Bandung: CV. Alfabeta.

Sulisworo, D., Agustin, S. P., \& Sudarmiyati, E. (2016). Cooperative-blended learning using Moodle as an open source learning platform. International Journal of Technology Enhanced Learning, 8(2), 187-198.

Teo, T., Zhou, M., Fan, A. C. W., \& Huang, F. (2019). Factors that influence university students' intention to use Moodle: A study in Macau. Educational Technology Research and Development, 67(3), 749-766.

Van Leeuwen, T. (2008). Discourse and practice: New tools for critical discourse analysis. Oxford University Press.

Yudar, R. S., Aditomo, D. T., \& Silalahi, N. S. (2020). Movie as a Helper for Students' Pronunciation in Speaking Skill Class. ELSYA: Journal of English Language Studies, 2(1), 15-19.
Zulkarnain, L. (2012). Use of Statistics in Social Research. Medan: Prime Publishing . 